\title{
PENERAPAN PROGRAM BADAN USAHA MILIK DESA (BUMDES) DALAM PENGELOLAAN POTENSI DAN SUMBER DAYA
}

\section{(STUDI DESA SINDANGJAYA KECAMATAN CIPANAS KABUPATEN CIANJUR)}

\section{IRGI NAZRI ADLANI}

Jurusan Administrasi Publik, Fakultas Ilmu Sosial dan Ilmu Politik, Universitas Islam Negeri Sunan Gunung Djati Bandung

Email: nazriirgi@gmail.com

HP: 081931321682

\begin{abstract}
Sindang Jaya Village Government established BUMDes as a motor of economic driving in rural areas through Bumdes program that has been made because through Bumdes facility ordinary people get capital for entrepreneurship and more independent in managing the potential of natural resources in Sindangjaya Village but in its formation is still minimal coaching from Local Government so that some problems arise, such as how the content of Bumdes program, and how its implementation as well as bagamanakah obstacles in managing the potential of village sindangjaya.Hasil research shows that the contents of the program Bumdes Sindang Jaya village is engaged in the type of business Social Business, Business Leasing Business Save Borrow other than that the implementation of BUMDes programs have been running well and Barriers in managing Bumdes and managing the potential Village natural resources on financial planning and agricultural products have not been well managed and proper target so that even though the program is already running but its content is not fully commonly felt by all people because of lack of knowledge in marketing the existing natural resources.
\end{abstract}

KEYWORDS: Implementation; Program; Bumdes.

ABSTRAK. Pemerintah Desa Sindang Jaya membentuk BUMDes sebagai motor penggerak ekonomi di pedesaan melalui program Bumdes yang sudah di buat karna melalui fasilitas Bumdes masyarakat biasa mendapatlan modal untuk berwirausaha serta lebih mandiri dalam mengelola potensi sumber daya alam yang ada di Desa Sindangjaya namun dalam pembentukkannya masih minim pembinaan dari Pemerintah Daerah sehingga muncul beberapa permasalahan, diantaranya adalah ada Bagaimanakah isi program Bumdes, dan Bagaimana Implementasinya serta bagamanakah hambatannya dalam mengelola potensi desa sindangjaya.Hasil penelitian menunjukkan bahwa isi program Bumdes desa sindang Jaya adalah bergerak di bidang jenis usaha Bisnis Sosial, Bisnis Penyewaan Bisnis Simpan Pinjam selain itu implementasi pelaksanaan program-program BUMDes telah berjalan secara baik dan Hambatannya dalam mengelola Bumdes serta mengelola potensi Sumber daya alam desa mengenai perencanaan keuangan dan hasil bumi belum terkelola dengan baik dan tepat sasaran sehingga meskipun program tersebut sudah berjalan akan tetapi hasinya belum sepenuhnya biasa 
dirasakan oleh semua masyarakat karna minimnya pengetahuan dalam memasarkan hasil sumber daya alam yang ada.

Kata Kunci : Penerapan; Program; Bumdes.

\section{PENERAPAN PROGRAM BADAN USAHA MILIK DESA (BUMDES) DALAM PENGELOLAAN POTENSI DAN SUMBER DAYA}

\section{(STUDI DESA SINDANGJAYA KECAMATAN CIPANAS KABUPATEN CIANJUR)}

\section{A. PENDAHULUAN}

Pemerintah desa merupakan subsistem dari sistem penyelenggaraan pemerintahan daerah sehingga desa memiliki kewenangan untuk mengatur dan mengurus kepentingan masyarakatnya dalam kerangka otonomi desa itu sendiri. Sebelum kita melangkah lebih lanjut mengenai otonomi desa ini, alangkah baiknya kita mengetahui terlebih dahulu arti dari kedua kata tersebut yaitu otonomi dan desa. Budiono Bambang (2000:32) mengemukakan bahwa pengembangan basis ekonomi di pedesaan sudah semenjak lama dijalankan oleh Pemerintah melalui berbagai program. Namun upaya itu belum membuahkan hasil yang memuaskan sebagaimana diinginkan bersama. Terdapat banyak faktor yang menyebabkan kurang berhasilnya program-program tersebut. Salah satu faktor yang paling dominan adalah intervensi Pemerintah terlalu besar, akibatnya justru menghambat daya kreativitas dan inovasi masyarakat desa dalam mengelola dan menjalankan mesin ekonomi di pedesaan.

Sistem dan mekanisme kelembagaan ekonomi di pedesaan tidak berjalan efektif dan berimplikasi pada ketergantungan terhadap bantuan Pemerintah sehingga mematikan semangat kemandirian. Belajar dari pengalaman masa lalu, satu pendekatan baru yang diharapkan mampu menstimulus dan menggerakkan roda perekonomian di pedesaan adalah melalui pendirian kelembagaan ekonomi yang dikelola sepenuhnya oleh masyarakat desa. Lembaga ekonomi ini tidak lagi didirikan atas dasar instruksi Pemerintah.

Tetapi harus didasarkan pada keinginan masyarakat desa yang berangkat dari adanya potensi yang jika dikelola dengan tepat akan menimbulkan permintaan di pasar. Pendirian lembaga ini antara lain dimaksudkan untuk mengurangi peran para tengkulak yang seringkali menyebabkan 
meningkatnya biaya transaksi (transaction cost) antara harga produk dari produsen kepada konsumen akhir. Melalui lembaga ini diharapkan setiap produsen di pedesaan dapat menikmati selisih harga jual produk dengan biaya produksi yang layak dan konsumen tidak harus menanggung harga pembelian yang mahal. Membantu kebutuhan dana masyarakat yang bersifat konsumtif dan produktif. Menjadi distributor utama untuk memenuhi kebutuhan pokok masyarakat (Kapokmas). Disamping itu, berfungsi menumbuh suburkan kegiatan pelaku ekonomi di pedesaan.

Bumdes memiliki peran untuk meningkatkan sarana perekonomian dan meningkatkan kesejahteraan masyarakat desa. Pemerintah pusat hingga ke daerah kota maupun kabupaten sangat mendorong masyarakat mempunyai usaha dalam mendorong dan menekan angka pengangguran sesuai peraturan yang berlaku di Indonesia hingga daerahnya. Undang undang No 6 tahun 2014 pasal 1 ayat 6 tentang Badan Usaha Milik Desa adalah badan usaha yang seluruh atau sebagian besar modalnya dimiliki oleh Desa melalui penyertaan secara langsung yang berasal dari kekayaan Desa yang dipisahkan guna mengelola aset, jasa pelayanan, dan usaha lainnya untuk sebesarbesarnya kesejahteraan masyarakat Desa. Dan pada pasal 87 tentang badan usah miliki desa bahwa :

1. Desa dapat mendirikan Badan Usaha Milik Desa yang disebut BUM Desa.

2. BUM Desa dikelola dengan semangat kekeluargaan dan kegotongroyongan.

3. BUM Desa dapat menjalankan usaha di bidang ekonomi dan/atau pelayanan umum sesuai dengan ketentuan peraturan perundang-undangan.

Bumdes diharapkan memiliki peran serta memajukan masyarakat didalam bidang ekonomi. Dalam pelaksanaan bumdes tersebut sesuai dengan UU No 6 tahun 2014 pasal 1 ayat 6 bahwa peran desa merupakan vital karena pemerintah desa yangMembangun bumdes tersebut dan juga bumdes harus dengan kesadaran kerja sama pelaksanaan dan pembangunannya. Seperti desa yang menjalankan dan masyarakat harus ikut andil mengawasi dalam pelakasanaannya agar sesuai dengan ketentuan peraturan perundang - undangan.

Dalam peraturan pemerintah tentang badan usaha milik desa (BUMDES) Bagian Kesatu Pendirian dan Organisasi Pengelola pada Pasal 132 bahwa : 
1. Desa dapat mendirikan BUM Desa.

Pembentukan dan pengelolaan

2. Pendirian BUM Desa sebagaimana dimaksud pada ayat dilakukan melalui musyawarah Desa dan ditetapkan dengan peraturan Desa.

3. Organisasi pengelola BUM Desa terpisah dari organisasi Pemerintahan Desa.

4. Organisasi pengelola BUM Desa sebagaimana dimaksud pada ayat (1) paling sedikit terdiri atas:

a. penasihat; dan

b. pelaksana operasional.

5. Penasihat sebagaimana dimaksud pada ayat (4) huruf a dijabat secara ex-officio oleh kepala Desa.

6. Pelaksana operasional sebagaimana dimaksud pada ayat (6) dilarang merangkap jabatan yang melaksanakan fungsi pelaksana lembaga Pemerintahan Desa dan lembaga kemasyarakatan Desa. dimaksud pada ayat (4) huruf b merupakan perseorangan yang diangkat dan diberhentikan oleh kepala Desa.

7. Pelaksana operasional sebagaimana

Berdasarkan peraturan perda Kabupaten cianjur dalam mendorong dan memberikan tata cara dan pengelolaan Badan usaha milik desa. Sesuai dalam Perda cianjur ayat 3 tahun 2012 pasal 5 bahwa dalam peran desa dan strategi Badan Usaha Milik desa harus terwujudnya kesejahteraan masyarakat desa dan untuk menumbuh kembangkan ekonomi masyarakat melalui kesempatan berusaha, pemberdayaan masyarakat, dan pengelolaan aset milik desa sesuai kebutuhan dan potensi desa, maka 
Pemerintah Desa diberi kewenangan untuk membentuk dan mengelola Badan Usaha Milik Desa.

Sebagai level pemerintahan terendah, pemerintah desa sebagai ujung tombak dalam sistem pemerintahan daerah akan berhubungan dan bersentuhan langsung dengan masyarakat dengan tujuan untuk mensejahterakan masyarakat dari atas hingga bawah. Karena itu, sistem dan mekanisme penyelenggaraan pemerintahan daerah sangat didukung dan ditentukan oleh pemerintah desa sebagai bagian dari pemerintah daerah. Reformasi dan otonomi daerah sebenarnya adalah harapan baru bagi pemerintah dan masyarakat desa untuk membangun desanya sesuai kebutuhan dan aspirasi masyarakat. Sebagian besar aparat pemerintah desa, otonomi adalah suatu peluang baru yang dapat membuka ruang kreatifitas bagi aparatur desa dalam mengelola desa sesuai dengan sumber daya yang dimiliki baik yang berupa sumber daya alam maupun dengan sumber daya manusia.

Undang-Undang Nomor 23 Tahun 2014 tentang Pemerintahan Daerah membawa penyempurnaan baru terhadap penyelenggaraan Pemerintahan mulai dari Pemerintah Daerah sampai kepada Pemerintahan Desa. Undang-Undang ini telah memberikan otonomi yang jauh lebih besar kepada Daerah otonom terutama Daerah Kabupaten/Kota. Pemerintahan Desa secara yuridis formal diakui dalam UndangUndang Nomor 6 Tahun 2014 tentang Desa, dan Peraturan Pemerintah Nomor 43 Tahun 2014 tentang Peraturan Pelaksana UndangUndang Nomor 6 Tahun 2014 tentang Desa.

Dalam Undang-Undang Nomor 6 Tahun 2014 disebutkan bahwa Desa adalah desa dan desa adat atau yang disebut dengan nama lain, selanjutnya disebut Desa, adalah kesatuan masyarakat hukum yang memiliki batas wilayah yang berwenang untuk mengatur dan mengurus urusan pemerintahan, kepentingan masyarakat setempat berdasarkan prakarsa masyarakat, hak asal usul, dan/ atau hak tradisional yang diakui dan dihormati dalam sistem pemerintahan Negara Kesatuan Republik Indonesia.

Pemerintah Desa dilaksanakan oleh Kepala Desa sebagai Badan Eksekutif dan Badan Permusyawaratan Desa (BPD) sebagai Badan Legislatif. Pemerintah inilah yang selanjutnya mengayomi masyarakat serta mengurus kepentingan desa dalam bidang pemerintahan, dan pembangunan. Walaupun desa memiliki Alokasi Dana Desa (ADD) yang berasal dari Anggaran Pendapatan Belanja Daerah (APBD) Kabupten, namun diperlukan juga suatu 
badan yang mengurus kekayaan asli desa demi terjadinya keseimbangan dan pembangunan. Untuk itu perlu suatu lembaga yang dapat mengelola potensi desa dengan maksimal maka didirikanlah Badan Usaha Milik Desa (BUMDesa) yang modalnya berasal dari kekayaan desa seperti industri masyarakat, pertanian, pertenakan, perdaganga, pariwisata dan lain-lain.

Badan Usaha Milik Desa (BUMDesa) merupakan lembaga usaha desa yang dikelola oleh masyarakat dan pemerintahan desa dalam upaya memperkuat perekonomian desa dan dibentuk berdasarkan kebutuhan dan potensi desa. Cara kerja BUMDesa adalah dengan jalan menampung kegiatan-kegiatan ekonomi masyarakat dalam sebuah bentuk kelembagaan atau badan usaha yang dikelola secara profesional, namun tetap bersandar pada potensi asli desa. Hal ini dapat menjadikan usaha masyarakat lebih produktif dan efektif.

Lahirnya lembaga seperti BUMDesa, diharapkan akan menjadi lembaga yang menampung kegiatan ekonomi masyarakat yang berkembang menurut ciri khas desa dalam rangka meningkatkan kesejahteraan masyarakat desa sebagai tempat kehidupan dan penghidupan. Bahkan lebih dari itu, Desa diharapkan akan menjadi fondasi penting bagi kemajuan bangsa dan negara dimasa yang akan datang. Terbentuknya Badan Usaha Milik Desa di mulai dari lahirnya Undang - undang No. 32 tahun 2004 beserta Peraturan Pemerintah No. 72 tahun 2005 dan Peraturan menteri dalam negeri No. 39 tahun 2010 merupakan kebijakan yang telah memberikan kesempatan ruang, petunjuk maupun payung hukum terhadap BUMDesa.

\begin{tabular}{lrr}
\multicolumn{2}{c}{ Permendagri } & juga mengandung \\
substansi yang & inovatif. & Pertama, \\
pembentukan $\quad$ BUMDesa & bersifat
\end{tabular}
kondisional, yakni membutuhkan sejumlah persyaratan, yang menjadi dasar kelayakan pembentukan BUMDesa. Dalam pasal 5 ditegaskan tentang syarat-syarat pembentukan BUMDesa sebagai berikut :

a. Atas inisiatif pemerintah desa dan atau masyarakat berdasarkan musyawarah warga desa.

b. Adanya potensi usaha ekonomi masyarakat.

c. Sesuai dengan kebutuhan masyarakat, terutama dalam pemenuhan kebutuhan pokok.

d. Tersedianya sumber daya desa yang belum dimanfaatkan secara optimal, terutama kekayaan desa.

e. Tersedianya sumber daya manusia yang mampu mengelola 
badan usaha sebagai aspek penggerak perekonomian masyarakat desa.

f. Adanya unit-unit usaha masyarakat yang merupakan kegiatan ekonomi warga masyarakat yang dikelola secara parsial dan kurang terakomodasi;dan

g. Untuk meningkatkan pendapatan masyarakat dan pendapatan asli desa.

Kedua, BUMDesa merupkan usaha desa yang bercirikan kepemilikan kolektif, bukan hanya dimiliki oleh pemerintah desa, bukan hanya dimiliki masyarakat, bukan juga hanya dimiliki oleh individu, melainkan menjadi milik pemerintah desa dan masyarakat. Ketiga, mekanisme pembentukan BUMDesa bersifat inklusif, deliberative dan partisipatoris, Artinya BUMDesa tidak cukup dibentuk oleh pemerintah desa, tetapi debentuk melalui musyawarah desa yang melibatkan berbagai komponen masyarakat. Secara organisasional musyawarah desa juga dilembagakan sebagai institusi tertinggi dalam BUMDesa seperti hal nya rapat anggota dalam koperasi.
Keempat, pengelolaan BUMDesa bersifat demokratis dan teknokratis. Dimensi teknokrasi terlihat dalam bentuk dalam pembagian kerja yang jelas, dimensi demokrasi tidak hanya terlihat pada komponen musyawarah desa tetapi juga di tunjukan pada komponen akuntabilitas. Pemisahan organisasi maupun asset BUMDesa dari pemerintahan desa merupakan komponen penting untuk menjaga akuntabilitas BUMDesa. Kebijakan di atas, khususnya Permendagri No. 39/2010 dan fasilitasi Kementerian Dalam Negeri dan kebijakan Pemerintah Kabupaten, merupakan factor utama yang melahirkan BUMDesa di banyak desa dan daerah.

Badan Usaha Milik Desa (BUMDesa) dalam pandangan hukum, diatur dalam Undang-Undang Nomor 6 Tahun 2014 tentang Desa Pasal 72ayat (1) huruf a yang menyatakan pendapatan asli desa terdiri atas hasil usaha, hasil aset, swadaya dan partisipasi, gotong royong, dan lain-lain pendapatan asli desa. Berdasarkan penjelasan dari Pasal 72 ayat (1) huruf a yang dimaksud dengan pendapatan asli desa adalah pendapatan yang berasal dari kewenangan desa berdasarkan hak asal-usul dan kewenangan skala desa. Kemudian yang dimaksud hasil usaha adalah termasuk hasil 
dari BUMDesa. Selanjutnya BUMDesa diatur dalam pasal 87 pada ayat 1 dan 3 yang menyatakan desa dapat mendirikan BUMDesa yang dikelola dengan semangat kekeluargaan dan gotong-royongan.

BUMDesa dapat menjalankan usaha di bidang ekonomi dan/atau pelayanan umum sesuai degan ketentuan peraturan perundang-undangan. Pengaturan lebih lanjut mengenai BUMDesa diatur dalam Peraturan Menteri Desa, Pembangunan Daerah Tertinggal, Dan Transmigrasi Republik Indonesia Nomor 4 Tahun 2015 Tentang Pendirian, Pengurusan Dan Pengelolaan, dan Pembubaran Badan Usaha Milik Desa. Adapun tujuan pendirian Badan Usaha Milik Desa dalam Peratura menteri desa Nomor 4 Tahun 2015 BUMDesa didirikan dengan tujuan sebagai berikut:

1. Meningkatkan perekonomian Desa.

2. Mengoptimalkan asset Desa agar bermanfaat untuk kesejahteraan Desa.

3. Meningkatkan usaha masyarakat dalam pengelolaan potensi ekonomi Desa.

4. Mengembangkan rencana kerja sama usaha antar Desa dan/atau dengan pihak ketiga.
5. Menciptakan peluang dan dan jaringan pasar yang mendukung kebutuhan layanan umum warga.

6. Membuka lapangan kerja.

7. Meningkatkan kesejahteraan masyarakat melalui perbaikan pelayanan umum, pertumbuhan dan pemerataan ekonomi Desa.

8. Meningkatkan pendapatan masyarakat Desa dan Pendapatan Asli Desa.

Perekonomian pedesaan dengan model BUMDesa, diharapkan mampu untuk meningkatkan perekonomian masyarakat desa. Selain itu juga untuk menambah Pendapatan Asli Desa (PAD). Pemerintahan Desa yang setiap tahun membutuhkan Anggaran Pendapatan Belanja Desa (APBDES) dalam menjalankan roda pemerintahan setidaknya ada pendapatan yang bersumber asli dari desanya sendiri bukan hanya bergantung pada dana kucuran pemerintah diatasnya. Karena dari sinilah muncul kesadaraan akan pentingnya kemandirian desa, bukan berarti pemerintah pusat lepas tanggung jawab terhadap persoalan-persoalan pedesaan.

Pembentukan

BUMDesa

berdasarkan pada musyawarah yang diadakan oleh pemerintah desa dengan 
seluruh elemen masyarakat yang ada didesa. Setiap satu tahun sekali pemerintah desa melaksanakan kegiatan Musyawarah Perencanaan Pembangunan Desa (Musrembangdes) dari sinilah alur pembentukan BUMDes dimulai. Hasil Musrenbangdes yang berkenaan dengan pembentukan BUMDes ini dituangkan dalam bentuk Anggaran Dasar/Anggaran Rumah Tangga yang berisi tentang organisasi dan tata kerja, penetapan personil, sistem pertanggung jawaban dan pelaporan, bagi hasil dan kepailitan. Kemudian langkah selanjutnya perencanaan draft yang akan dituangkan kedalam bentuk Peraturan Desa. Berdasarkan perda kab cianjur no 3 tahun 2001 pasal 3 bahwa Pembentukan BUMDes bertujuan untuk:

a. meningkatkan pendapatan asli desa

b. mendorong berkembangnya kegiatan perekonomian masyarakat desa

c. meningkatkan kreativitas dan peluang usaha ekonomi produktif (berwirausaha) anggota masyarakat desa; dan

d. mendorong berkembangnya usaha mikro sektor informal untuk penyerapan tenaga kerja bagi masyarakat di desa
Sumber pendapatan diatas menjadi tumpuan perekonomian desa.sebagai pendapatan asli desa digunakan untuk pelaksanaan pembangunan, namun dalam pengelolaan perekonomian pemerintah desa pada kenyataannya belum berjalan dengan baik,sesuai dengan peraturan perundangundangan. Ekonomi desa pada umumnya sangat memprihatinkan dan banyak desa yang hanya mengandalkan bantuan dari pihak pemerintah saja. Hal tersebut tentu akan mempersulit pembangunan perekonomian desa. Pemerintah desa masih banyak yang merasa kesulitan dalam mendapatkan dan meningkatkan pendapatan asli desanya. Hal ini disebabkan keterbatasan dari sumber daya yang dimiliki baik sumber daya manusia maupun sumber daya alamnya. Komoditi itu yang menjadi unggulan pada suatu desa belum dapat dimanfaatkan dengan baik.

Sejauh dibuatkannya program kegiatan BUMDesa harus didasarkan pada kebutuhan dan potensi desa, sebagai upaya peningkatan kesejahteraan masyarakat. Berkenaan dengan perencanaan dan pendiriannya, BUMDesa dibangun atas prakarsa (ir isiasi) mas rarakat, serta mendasarkan pada prinsip-prinsip kooperatif, partisipatif, transparansi, 
emansipatif, akuntabel, dan sustainabel dengan. Dari semua itu yang terpenting adalah bahwa pengelolaan BUMDesa harus dilakukan secara profesional dan mandiri. Desa Sindangjaya adalah salah satu desa di kecamatan cipanas yang mempunyai luas wilayah $512 \mathrm{Ha}$. Desa sindangjaya mempunya jumlah penduduk sebanyak 13.255 jiwa. desa sindangjaya mempunyai potensi di bidang pertanian untuk meningkatkan ekonomi desa karena desa sindangjaya berada pada ketinggian antara 1000 sampai dengan 1.100 meter diatas permukaan laut.

Dataran tanah yang berbukit bukit dan serta kesuburan tanah yang tinggi dihubungkan dengan ketinggian tempat, curah hujan, dan iklim serta jenis tanah. Maka dari itu desa sindangjaya sangat cocok untuk usaha dibidang pertanian tanaman holtikultura, khususnya sayur mayor dataran tinggi (wortel, bawang daun, dan daun casein). disitulah bahwa masyarakat desa sindangjaya memiliki sasaran untuk mengelola dan membangun BUMDES di desa tersebut. Dalam kebijakan program pemerintah desa sindangjaya sangat mendorong sesuai dengan paparan potensi desa sindangjaya karena potensi alam sangat besar, maka harus dikelola dalam BUMDES agar terorganisir dan kesejahteraan masyarakat lebih tinggi.

Dalam pra penelitian pada hari senin tanggal 4 desember, peneliti menemukan fenomena tentang pengelolaan BUMDES tersebut belum berjalan secara efektif atau masih terbengkalai hanya baru 1 program yang berjalan yaitu pembangunan ruko untuk menunjang kegiatan roda badan usaha milik desa. Pemerintah desa juga memiliki perencanaan desa wisata agropolitan karena sesuai topografi dan kontur desa yaitu berbukit dan daerah pertanian, dan juga pengelolaan desa wisata tersebut dikelola oleh Badan Usaha Milik Desa (BUMDES), akan tetapi masih ditingkat perencanaan meskipun itu sebagai program kerja yang harus dilaksanakan.

Seperti tercantum dalam Rancangan pembangunan jangka menengah desa (RPJMDes) salah satunya kebijakan ditingkat pengembangan program desa seperti potensi desa yaitu program lahan wisata/hiburan akan dikelola oleh badan usaha milik desa (BUMDES). tetapi Badan Usaha milik desa memiliki beberapa masalah dalam pengelolaan dan pelaksanaannya. yaitu kurang percaya nya masyarakat kepada pihak bumdes karena mereka berpandangan bahwa organisasi tersebut akan mengambil alih atau 
mengeruk semua hasil dalam pengelolaan agro bisnis. Dan pihak bumdes pun belum mempercayai semua masyarakat karena bumdes pun berpandangan bahwa masyarakat akan sulit untuk mengembalikan modal pinjaman karena keuangan bumdes harus terus berputar.

Masyarakat desa sindangjaya tidak akan bisa menikmati hasil dari program bumdes tersebut meskipun organisasi bumdes bertujuan untuk memberikan kesejahteraan lewat program bumdes dalam mengelola potensi dan sumberdaya desa sindangjaya. Berdasarkan hal tersebut, maka peneliti merasa tertarik untuk melakukan penelitian dengan judul " PENERAPAN PROGRAM BADAN USAHA MILIK DESA (BUMDES) DALAM PENGELOLAAN POTENSI DAN SUMBER DAYA (STUDI DESA SINDANGJAYA KECAMATAN CIPANAS KABUPATEN CIANJUR)."

\section{B. KERANGKA KONSEPTUAL}

Dari teori yang dikemukakan oleh George C. Edward III dalam agustino (2008:149) yang mempengaruhi keberhasilan implementasai kebijakan dibagi menjadi empat variabel, diantaranya:

\section{Komunikasi}

Seperti halnya Menurut Edward III.

"komunikasi merupakan salah-satu variabel penting yang mempengaruhi implementasi kebijakan publik, komunikasi sangat menentukan keberhasilan pencapaian tujuan dari implementasi kebijakan publik". Implementasi yang efektif akan terlaksana, jika para pembuat keputusan mengetahui mengenai apa yang akan mereka kerjakan. Infromasi yang diketahui para pengambil keputusan hanya bisa didapat melalui komunikasi yang baik.

\section{Struktur Birokrasi}

Menurut George C. Edwards III Struktur Birokrasi dalam pencapaian sebuah kebijakan dalam implementasi Birokrasi merupakan salah-satu institusi yang paling penting bahkan sering menjadi pelaksana kegiatan. Keberadaan birokrasi tidak hanya dalam struktur pemerintah, tetapi juga ada dalam organisasi-organisasi swasta, institusi pendidikan dan sebagainya. Bahkan dalam kasus-kasus tertentu birokrasi diciptakan hanya untuk menjalankan suatu kebijakan tertentu.

\section{Sikap}

pelaksanaan

\section{(Disposisi)}

Menurut Edward III

mengemukakan

'kecenderungan-

kecenderungan atau disposisi merupakan 
salah-satu faktor yang mempunyai konsekuensi penting bagi implementasi kebijakan yang efektif”. Jika para pelaksana mempunyai kecenderungan atau sikap positif atau adanya dukungan terhadap implementasi kebijakan maka terdapat kemungkinan yang besar implementasi kebijakan akan terlaksana sesuai dengan keputusan awal. Demikian sebaliknya, jika para pelaksana bersikap negatif atau menolak terhadap implementasi kebijakan karena konflik kepentingan maka implementasi kebijakan akan menghadapi kendala yang serius.

\section{Sumber Daya}

Menurut Edward III sumber daya merupakan hal penting dalam implementasi kebijakan yang baik Indikator-indikator yang digunakan untuk melihat sejauhmana sumber daya mempengaruhi implementasi kebijakan terdiri dari Staf Sumber daya utama dalam implementasi kebijakan adalah staf atau pegawai (street-level bureaucrats).

\section{METODE PENELITIAN}

Penelitian ini menggunakan pendekatan kualitatif. Hal ini disebabkan karena peneliti berkeinginan kuat untuk memahami dan mengamati secara lebih mendalam secara detail dan luas tentang bagaimana penerapan dan pengelolaan Sumber daya oleh BUMDesa di Desa Sindangjaya Kecamatan Cipanas Kabupaten Cianjur. Menurut Nasution (1996:3) pendekatan kualitatif pada hakekatnya ialah "mengamati orang dalam lingkungan hidupnya atau kebijakan yang dibuat, berinteraksi dengan mereka, berusaha memahami bahasa mereka, tentang dunia sekitar. Penelitian deskriptif dapat diartikan mengadakan penggambaran yang lebih jelas tentang situasi-situasi sosial".

Dalam penelitian ini untuk menganalisis, peneliti menggunakan teknik puprosive sampling. Purposive sampling (sampel bertujuan) adalah teknik pengambilan sampel sumber data dengan pertimbangan tertentu. 


\section{PEMBAhASAN}

\section{Bagaimanakah penerapan rogram Badan Usaha Milik Desa (BUMDES) dalam mengelola} potensi dan Sumber Daya Desa ?

Pemerintah Desa Sindang jaya telah menyusun anggaran dasar Bumdes dengan sebagaimana amanat dari Undang undang Nomor 6 Tahun 2014 tentang desa serta menindak lanjuti dari pelaksanaan Bumdes berdasarkan pasal 136 PP Nomor 43 Tahun 2015 tentang peraturan pelaksana Desa dan Peraturan Bupati Cianjur Nomor. 85 Tahun 2014 Tentang Tata Cara Pembentukkan dan Pengelolaan Badan Usaha Milik Desa Undang Undang Desa yang salah satu tujuaannya adalah menjadikan Bumdes di wilayah Kab.Cianjur khususnya desa Sindang Jaya merupakan menjadikan Instrumen Pendayagunaan ekonomi Lokal dengan beragam jenis potensi yang ada.

BUMDes menjadi tulang punggung perekonomian pemerintahan desa guna mencapai peningkatan kesejahteraan warganya, Sementara itu. untuk jenis usaha yang dapat dikembangkan melalui BUMDes diantaranya, usaha bisnis sosial melalui usaha air minum desa, usaha listrik desa dan lumbung pangan, usaha bisnis penyewaan melalui usaha alat transportasi, perkakas pesta, gedung pertemuan, rumah toko dan tanah milik BUMDes dan usaha bersama (holding) sebagai induk dari unit-unit usaha yang dikembangkan melalui pengembangan dan desa wisata.

Sebagaimana yang tertuang dalam Program jenis usaha dalam BUMDES Sugih Jaya terbagi 6 klasifikasi sebagai berikut:

\section{a. Bisnis Sosial}

Jenis usaha bisnis sosial dalam BUMDES yakni dapat melakukan pelayanan publik kepada masyarakat. Dengan kata lain memberi keuntungan sosial kepada warga, meskipun tidak mendapatkan keuntunggan yang besar.

b. Bisnis Uang

BUMDES menjalankan bisnis uang yang memenuhi kebutuhan keuangan masyarakat desa dengan bunga yang lebih rendah daripada bunga uang yang didapatkan masyarakat desa dari para rentenir desa atau bank-bank konvensional.

c. Bisnis Penyewaan

BUM Desa menjalankan bisnis penyewaan untuk melayani kebutuhan masyarakat setempat dan sekaligus untuk memperoleh pendapatan desa.

d. Lembaga Perantara

BUM Desa menjadi "lembaga perantara" yang menghubungkan komoditas pertanian dengan pasar atau agar para petani tidak kesulitan menjual produk mereka ke pasar. Atau BUM Desa menjual jasa pelayanan kepada warga dan usaha-usaha masyarakat.

e. Trading/perdagangan

BUM Desa menjalankan bisnis yang berproduksi dan/atau berdagang barangbarang tertentu untuk memenuhi kebutuhan masyarakat maupun dipasarkan pada sekala pasar yang lebih luas.

\section{f. Usaha Bersama}

BUM Desa sebagai "usaha bersama", atau sebagai induk dari unit-unit usaha 
yang ada di desa, dimana masingmasing unit yang berdiri sendiri-sendiri ini, diatur dan ditata sinerginya oleh BUM Desa agar tumbuh usaha bersama.

Mengenai tentang pelaksanaan program Bumdes Sugih Jaya dalam mengelola potensi desa masyarakat di wajibkan ikut serta dalam ke anggotaan Bumdes Sugih Jaya karna dengan di terbikan Nomor Induk anggota Bumdes masyarakat bisa menikmati programprogram bantuan pemerintah desa sindang jaya salah satunya adalah:

\section{a. Pelaksanaan Program koperasi desa}

Koperasi desa menyiapkan segala kebutuhan pokok masyarakat demi meningkatkan ekonomi masyarakat desa seperti halnya, menjual bahan sembako yang harganya lebih terjangkau dari pada harga pasar. Selain itu koperasi desa juga menyiapkan bahan pokok pertanian seperti halnya pupuk, bibit, pestisida, dll. Serta kebutuhan peternakan seperti pakan ternak, ikan, ayam, bebek. juga bibit unggulan seperti ayam potong, benih ikan mas anak domba dan bebek. Pelaksanaannya masyarakat desa yang keikutsertaan sebagai keanggotaaan bumdes bisa mendapatkan fasilitas tersebut dengan syarat mengikuti ketentuan yang berlaku yang telah disepakati bersama.

\section{b. Pelaksanaan Program Usaha Ekonomi (PNPM)}

Pelaksanaannya diharapkan mendorong masyarakat desa untuk dapat bisa membuka peluang usaha mandiri dengan mendapatkan pinjaman modal usaha seperti halnya masyarakat desa bisa menyimpan uang melalui program simpan pinjam (PNPM) yang diharapkan masyarakat bisa mempercayai untuk menyimpan uang selain bank swasta yang ada diwilayah kabupaten cianjur, Karena selain memiliki jarak tempuh yang dekat, PNPM Bumdes juga dapat dipercaya menyimpan uang masyarakat dengan bunga yang tidak begitu tinggi dibandingkan bank

- bank konvensional lainnya. Selain itu pinjaman modal usaha juga dapat diberikan kepada masyarakat sesuai dengan kebutuhan masing - masing dengan mempertimbangkan jenis dan kegiatan usaha yang akan dilakukan.

\section{c. Pelaksanaan Program Pertanian Agro Bisnis \\ Program ini diharapkan} memaksimalkan sumberdaya yang nantinya masyarakat sendiri dapat menikmati sendiri hasilnya dengan memperhatikan alam yang subur desa sindangjaya. Masyarakat desa bisa memanfaatkan sumberdaya alam yang ada seperti halnya bumdes menyiapkan bibit 
sayuran beserta pupuknya untuk dapat dimanfaatkan yang nantinya masyarakat itu sendiri yang akan mengelola dan mendapatkan hasilnya. Selain itu bumdes juga menyediakan bibit ikan mas, anak domba dan bebek yang akhirnya masyarakat itu sendiri dapat menikmati fasilitas yang diberikan pemerintah desa dengan syarat sebagaiman diatur dalam ketentuan kebijakan pemerintah desa.

Penggunaan dan tata cara pembagian keuntungan dari hasil bumdes. Pendapatan bersih diperoleh dari hasil transaksi dikurangi dengan pengeluaran biaya dan kewajiban dari pihak lain serta pengusutan ata barang - barang inventaris dalam satu tahun pembukuan. Pembagian pendapatan bersih di tetapkan berdasarkan musyawarah penasihat dan pengelola tetapkan berdasarkan musyarawah penasihat dan pengelola badan usaha milik desa, setelah dikurangi biaya operasional dengan ketentuan :

a. Pemupukan Modal Usaha

$$
: 20 \%
$$

b. Pendapatan Asli Desa

$$
: 20 \%
$$

c. Pendidikan dan Pelatihan Pengurus : $7 \%$

d. Komisaris

$$
\text { : } 7 \%
$$

e. Pengawas

$$
\text { : } 5 \%
$$

f. Honor Pengelola

$$
\text { : } 30 \%
$$

g. Biaya Rapat

$$
\text { : } 5 \%
$$

h. Dana Sosial

$$
\text { : } 2 \%
$$

i. Dana Cadangan

$$
\text { : } 4 \%
$$

j. Bagi masyarakat yang menggunakan pemanfaatan Bumdes dapat dikenakan biaya keterlambatan biaya angsuran sesuai dengan batas waktu keterlambatan biaya angsuran sesuai dengan batas waktu yang ditentukan setiap tanggal 10 dikenakan sanksi denda sebesar Rp. 10.000 bagi yang mengikuti program simpan pinjam. Untuk yang mengikuti program pertanian agro bisnis dan peternakan yang menjual atau melelang ternaknya tanpa seizini pengelola bumdes wajib mengembalikan permodalan serta jasa sebesar $15 \%$ pertahun. 
k. Keuntungan usaha dari jasa layanan koperasi dikenakan biaya iuran perbulannya sebesar Rp. 5.000 bilamana tidak dibayarkan, penerima atau anggota koperasi harus mengembalikan barang atau uang sesuai dengan apa yang diterima dari layanan koperasi. Semuanya untuk menciptakan masyarakat yang produktif serta membelikan pelayanan yang maksimal serta menggali potensi desa untuk didaya gunakan dan membuka wirausaha baru desa Sindangjaya Kecamatan Cipanas Kabupaten Cianjur.

\section{E. SIMPULAN}

1. Isi Program Badan Usaha Milik Desa Bumdes yang menjadi Program unggulan adalah jenis usaha Bisnis Sosial, sasaranya dapat melakukan pelayanan publik kepada masyarakat, Bisnis Penyewaan yaitu bisnis penyewaan kios-kios di tempat wisata untuk kebutuhan masyarakat setempat, Lembaga Perantara yaitu yang menghubungkan komoditas pertanian dengan pasar, selain itu ada Simpan Pinjam yakni menjalankan bisnis pinjaman untuk kebutuhan usaha maupun tabungan bagi masyarakat Desa

2. Penerapan pelaksanaan program Bumdes sudah berjalan dengan baik sesuai dengan Perdes yang ada, Manfaat dari Pelaksanaan Program koperasi desa dan Program Program Usaha Ekonomi (PNPM) serta Program Pertanian Agro Bisnis sudah biasa dirasakan oleh Masyarakat Desa Sindang Jaya.

3. Hambatannya adalah Sumberdaya Manusia yang ada dalam pelaksanaan program BUMDes ini secara kuantitas sangat kurang, salah satunya sosialisai yang kurang kepada masyarakat baik oleh pengurus Bumdes maupun Perangkat Desa, dari segi kualitas, sumber daya yang ada tidak terlalu faham teknologi IT seperti Komputer sehingga masih dilakukan pembukuan secara manual.

\section{F. Saran}

Setelah penulis memberikan kesimpulan dari hasil penelitian tentang Penerapan Program Badan Usaha Milik 
Desa (BUMDes) dalam Pengelolaan Potensi dan Sumber Daya (studi desa sindangjaya Kecamatan Cipanas Kabupaten Cianjur) penulis akan memberikan beberapa saran yang dapat digunakan oleh pemerintah Desa Sindangjaya Kecamatan Cipanas Kabupaten Cianjur, yaitu sebagai berikut :

\section{a. Saran Akademis}

Peneliti mengharapkan agar penelitian ini dapat berguna bagi mahasiswa yang melakukan penelitian serupa atau melakukan penelitian lanjutan atas topik yang sama. Peneliti berharap agar topik yang telah dipaparkan dapat menimbulkan rasa keingintahuan dalam meningkatkan ekonomi desa dengan mengelola sumber daya dan potensi desa dengan cara wawancara guna dapat mendapatkan hasil yang maksimal.

\section{b. Saran Kebijakan}

1. Diharapkan untuk jenis program Bumdes periode Pemerintahan Kepala Desa yang akan datang lebih terperinci dalam menyusun jenis jenis dan isi program sesuai dengan kebutuhan masyarakat dengan memperhatikan perkembangan jaman sehingga pengelolaan objek wisata, usaha pertanian dan perdagangan di Desa sindangjaya mengikuti perkembangan globalisasi yang ada.

2. Diharapkan pengelolaan dan pelaksanaan Bumdes di Desa Sindang Jaya lebih di tingkatkan kualitas pelayanannya serta sosialisasi secara menyeluruh ke kalangan masyarakat baik oleh panitia Bumdes maupun oleh perangkat Desa serta lebih di mudahkan bagi masyarakat berpenghasilan rendah untuk dapat di ikut sertaan menjadi anggota Bumdes Desa Sindang Jaya.

\section{c. Saran Praktis}

Administratif belum terkelola dengan baik, hal ini dikarenakan pengelola masih melakukan pembukuan secara manual dan tidak rutin dalam melakukan penginputan data sehingga peneliti kesulitan dalam mendapatkan data, Meningkatkan pengelolaan BUMDes dengan menggunakan manajemen Komputer yang baik sehingga data yang ada tidak tercecer dan tersimpan rapi dalam dokumen penting BUMDes. Sehingga saat data tersebut dibutuhkan akan mudah dicari dan mudah dalam membuat laporan pertanggung jawaban.

\section{DAFTAR PUSTAKA}

\section{Buku Text :}


Abidin, Said Zainal. (2012). Pengantar Kebijakan Publik. Jakarta: Salemba Humanika

Agustino, Leo. (2008). Dasar-Dasar Kebijakan Publik, Bandung: Alfabeta. Agustino. (2008). Politik dan Kebijakan Publik. Bandung: Asosiasi Ilmu Politik Indonesia (AIPI) dan Puslit KP2W Lembaga Penelitian Unpad

Ali, Farid dan Andi Syamsu Alam. (2012). Studi Kebijakan Pemerintah. Bandung: Refika Aditama

Anggara, Sahya. (2014). Kebijakan Publik. Bandung: Pustaka Setia

Dunn, William N. (2003). Pengantar Analisi Kebijakan Publik Edisi Kedua. Yogyakarta: Gadjah Mada University Press

Engkus. (2017). Administrasi Kepegawaian Indonesia Pada Sektor Publik (Dalam Pendekatan Aparatur Sipil Negeri). Bandung: Fisip Unpas Press

Irawan, Prasetya. (2005). Materi Pokok Metodologi Penelitian Administrasi. Jakarta: Universitas Terbuka.

Nugroho D. Riant. (2003). Kebijakan Publik : Formulasi Implementasi dan Evaluasi. Jakarta: Elex Media Komputindo

Parson. (2005). W.Public Policy Pengantar teori dan Praktek Analisis Kebijakan. Jakarta: Prenada Media.

Subarsono. (2012). Analisis Kebijakan Publik: Konsep, Teori, dan Aplikasi. Pustaka Belajar. Analisis Kebijakan Publik: Konsep, Teori, dan Aplikasi. Yogyakarta: Pustaka Belajar.
Sugiyono. (2009). Metode Penelitian Kuantitatif Kualitatif Dn $R \& D$. Bandung: Alfabeta.

Suharto, Edi. (2013). Kebijakan Sosial Sebagai Kebijakan Publik. Bandung : Alfabeta

Wahab, Abdul Solichin. (2013). Analisis Kebijaksanaan: dari Formulasi ke Impelementasi Kebijaksanaan Negara. Jakarta: Bumi Aksara

Wicaksono, Kristian Widya. (2006). Administrasi dan Birokrasi Pemerintah. Yogyakarta: Graha Ilmu

Widodo, Joko. (2010). Analisis kebijakan publik. Malang : Bayu Media

Winarno, Budi. (2005). Kebijakan Publik, dan Teori serta Proses. Jakarta: Media Pressindo

\section{Dokumen-Dokumen:}

Undang-undang Nomor. 32 Tahun 2004 Tentang Pemerintah Daerah

Undang-undang Nomor. 6 Tahun 2014 Tentang Desa

Peraturan Menteri Dalam Negeri Nomor. 39 Tahun 2010 Tentang Badan Usaha Milik Desa

Peraturan Menteri Desa Nomor. 4 Tahun 2015 Tentang Desa

Peraturan Daerah Nomor. 9 Tahun 2014 Tentang Desa

Peraturan Bupati Cianjur Nomor. 85 Tahun 2014 Tentang Tata Cara Pembentukkan dan Pengelolaan Badan Usaha Milik Desa 
Peraturan Desa Sindang Jaya Nomor. 7

Tahun 2013 Tentang Pembentukkan

Badan Usaha Milik Desa Mandiri

\section{Skripsi/Jurnal :}

Rustianawati Cintiya. (2013). Implementasi Kebijakan Pengadaan tanah untuk Pembangunan Bandara Internasional Jawa Barat (BLJB) di Kecamatan Kertajati Majalengka, Universitas Islam Negeri Sunan Gunung Djati, Bandung

Wijanarko, Septian. Agung. (2016). Peran Badan Usaha Milik Desa (BUMDes) Dalam pemberdayaan masyarakat. universitas pembangunan nasional veteran, jawa timur.

Fajarwati, Yeni. (2016). Implementasi Program Badan Usaha Milik Desa (BUMDes) Di Desa Pagedang Kabupaten Tangerang. Universitas Sultan Ageung Tirtayasa, Banten

Engkus. (2017). Administrasi Publik Dalam Perspektif Ekologi. Jurnal Ilmu Sosial dan Ilmu Politik. Volume (7) : 88 